\title{
PEMANFAATAN LIMBAH PERTANIAN DAN PETERNAKAN SEBAGAI PUPUK KOMPOS
}

\author{
ULTILIZATION OF AGRICULTURAL AND LIVESTOCK WASTEAS \\ A COMPOSTED FERTILIZER
}

\author{
${ }^{1)}$ Salfauqi Nurman, ${ }^{2)}$ Dewi Ermaya, ${ }^{2)}$ Fadlan Hidayat, ${ }^{2)}$ Rita Sunartaty \\ ${ }^{1)}$ Program Studi Teknologi Industri Pertanian, ${ }^{2)}$ Program Studi Teknologi Pangan \\ Fakultas Teknologi Pertanian, Universitas Serambi Mekkah \\ Jl. Umuha, Batoh, Banda Aceh \\ email: salfauqi.nurman@serambimekkah.ac.id
}

\begin{abstract}
ABSTRAK
Kegiatan ini bertujuan untuk memberikan pengetahuan, pelatihan dan pendampingan kepada masyarakat Gampong Keuneu Eu, Kecamatan Peukan Bada, Kabupaten Aceh Besar, Provinsi Aceh dalam mengolah limbah hasil pertanian dan peternakan menjadi pupuk kompos. Pelaksaan pengabdian kepada masyarakat ini dilakukan dengan penyuluhan tentang pupuk kompos, setelah itu dilakukan praktek pembuatan pupuk kompos. Hasil yang diperoleh yaitu berupa pupuk kompos yang dapat dimanfaatkan oleh masyarakat untuk pertanian sebagai pengganti penggunaan pupuk kimia, selain itu hasil lain dari program pengabdian ini berupa kemampuan yang diperoleh oleh masyarakat dalam mengelolah limbah hasil pertanian dan peternakan menjadi pupuk kompos, sehingga mengurangi penggunaan pupuk kimia dan mengurangi pencemaran lingkungan oleh limbah pertanian dan peternakan.
\end{abstract}

Kata kunci: Pendampingan, Pembuatan, Pupuk kompos

\section{ABSTRACT}

This dedication to the society aims to provide training to KeuneuEu village community, PeukanBada Sub-district, Aceh Besar District, Aceh Province to process agricultural and livestock waste into compost. Implementation of community service is done by counseling about compost fertilizer, after doing the practice of making compost fertilizer. The results obtained are in the form of compost fertilizers that can be utilized by the community for agriculture as a substitute for the use of chemical fertilizers, in addition to other results of this devotion program in the form of capabilities obtained by the community in managing agricultural and livestock waste into compost, thereby reducing the use of chemical fertilizers and reduce environmental pollution by agricultural and livestock waste.

Keyword: Assistance, Manufacture, Compost Fertilizer

Submited : 23 Mei $2018 \quad$ Revision : 31 Juli 2018 Accepted : 31 Oktober 2018

\section{PENDAHULUAN}

Kawasan Kecamatan Peukan Bada, Kabupaten Aceh Besar, Provinsi Aceh dengan luas wilayah mencapai $\pm 108 \mathrm{Ha}$, $50 \%$ dari luas wilayah tersebut digunakan untuk pertanian yang mencakup persawahan dan perkebunan. Secara fisik wilayah Gampong Keneu Eu memiliki keragaman sumber daya alam yang berpotensi, meliputi pertanian (tanaman pangan dan perkebunan) dan peternakan (lembu, kambing dan ayam). Berdasarkan hasil wawancara dengan Kepala Desa (Geuchik Gampong) Gampong Keuneu Eu, Yusran Zainun, bahwa Gampong Keuneu $\mathrm{Eu}$ terdiri dari 4 Dusun yaitu Dusun Kelapa, Dusun Bayi, Dusun Gelumpang dan Dusun Beringin, dengan jumlah penduduknya mencapai $143 \mathrm{KK}$ dan 528 
Jiwa yang terdiri dari laki-laki 258 jiwa dan perempuan 270 jiwa, $70 \%$ warganya memiliki mata pencaharian sebagai petani, data tersebut diambil dari data primer Gampong Keuneu Eu.

Limbah hasil pertanian dan peternakan di Gampong Keuneu Eu belum termanfaatkan dengan baik. Kurangnya pengetahuan masyarakat dalam pengolahan limbah tersebut menyebabkan limbah tersebut hanya menjadi bahan buangan yang dapat mencemari lingkungan. Pembuatan pupuk kompos merupakan salah satu cara yang dapat dilakukan untuk pengolahan limbah hasil pertanian dan peternakan(Nurhayati dkk , 2011).

Pupuk kompos merupakan merupakan salah satu pupuk organik yang dibuat dengan cara menguraikan sisa-sisa tanaman dan hewan dengan bantuan organisme hidup. Untuk membuat pupuk kompos diperlukan bahan baku berupa material organik dan organisme pengurai. Organisme pengurainya bisa berupa mikroorganisme ataupun makroorganisme (Firmansyah, 2010). Teknologi pengomposan dikembangkan dari proses penguraian material organik yang terjadi di alam bebas. Terbentuknya humus di hutan merupakan salah satu contoh pengomposan secara alami. Prosesnya berjalan sangat lambat, bisa sampai berbulan-bulan hingga bertahun-tahun (Rahmawanti \& Dony, 2014).

Pupuk kompos mudah dibuat dan teknologinya sederhana. Semua orang bisa mengerjakannya, baik untuk skala pertanian maupun sekadar keperluan pekarangan. Daerah pertania di Gampong Keuneu Eu, Kecamatan Peukan Bada, Kabupaten Aceh Besar, memiliki potensi pertanian yang besar,pupuk kompos merupakan kebutuhan masyarakat sekitar dalam mengembangkan pertanian tersebut.

Program pengabdian kepada masyarakat yang bertujuan untuk memberikan pengetahuan, pelatihan dan pendampingan kepada masyarakat dalam mengolah limbah hasil pertanian dan peternakan menjadi pupuk kompos, diharapkan masyarakat Gampong Keuneu $\mathrm{Eu}$ dapat memanfaatkan limbah hasil pertanian dan peternakan sebagai bahan baku pembuatan pupuk kompos. Sehingga masyarakat dapat mengurangi penggunaan, pupuk kimia yang berbahaya dan masyarakat juga dapat mengurangi tingkat pencemaran lingkungan yang disebabkan oleh limbah hasil pertanian dan peternakan

\section{METODE}

Mitra dari kegiatan pengabdian kepada masyarakat ini yaitu kelompok ibuibu tani Gampong Keuneu Eu, Kecamatan Peukan Bada, Kabupaten Aceh Besar, Provinsi Aceh. Pelatihan ini meliputi penyuluhan dan praktek pembuatan pupuk kompos.

Penyuluhan yang diberikan meliputi penyuluhan tentang bahayanya penggunaan pupuk kimia, pemanfaatan limbah pertanian sebagai bahan baku pembuatan pupuk kompos, manfaat pupuk kompos terhadap pertanian dan cara pembutan pupuk kompos.

Setelah diberikan penyuluhan, selanjutnya dilakukan praktek pembuatan pupuk kompos. Pembutan pupuk kompos menggunakan bahan-bahan dari limbah pertanian dan peternakan seperti skam padi/jerami, abu skam, daun-daun kering, batang pisang, dedak, kotoran sapi, kotoran kambing, kotoran ayam, aktivator, octobacte decomposer, EM4, dan tricoderma (Firmansyah, 2010; Rahmawanti \& Dony, 2014; Yanqoritha, 2013).

\section{HASIL DAN PEMBAHASAN}

Hasil yang diperoleh dari pengabdian kepada masyarakat ini adalah mitra memiliki pengetahuan sedikit banyaknya tentang bahayan penggunaan pupuk kimia terhadap diri sendiri dan 
terhadap lingkungan, mitra memiliki pengetahuan tentang pengolahan limbah pertanian menjadi pupuk kompos yang dapat dimanfaatkan kembali untuk pertanian dan mitra dapat membuat pupuk kompos sendiri dari limbah pertanian dan peternakan yang dapat dimanfaatkan kembali untuk pertanian, sehingga mengurangi penggunaan pupuk kimia yang berbahaya dan mengurangi tingkat pencemaran lingkungan yang disebabkan oleh limbah pertanian dan peternakan. Selain itu menggunakan pupuk kompos dapat menghemat pengeluaran mitra untuk membeli pupuk kimia.

Hasil lain dari kegiatan pengabdian kepada masyarakat ini yaitu berupa produk pupuk kompos yang memiliki sifat fisik yang baik dengan warna hitam dan tidak berbau busuk atau berbau khas pupuk kompos.

Proses pembuatan pupuk dapat dilihat dalam gambar berikut :

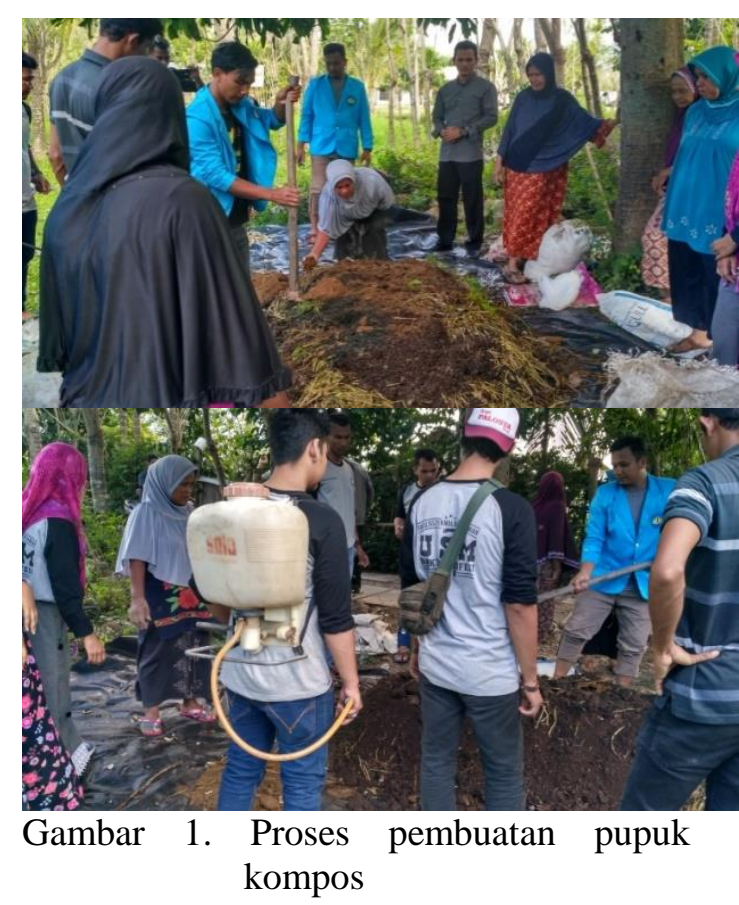

Pembuatan pupuk kompos pada dasarnya adalah proses penguraian limbah pertanian oleh mikroorganismen menjadi komponen-komponen yang lebih sederhana yang disebut unsur hara. Bahan baku pupuk kompos bisa diambil dari sisasisa tanaman dan atau kotoran hewan. Masing-masing bahan memiliki kandungan unsur-unsur yang berbeda. Unsur-unsur tersebut berfungsi sebagai zat hara yang diperlukan tanaman.

Dalam pembuatan pupuk kompos, sebaiknya diketahui tujuan pemupukan terlebih dahulu. Harusdiketahui zat apa yang paling dibutuhkan oleh tanaman yang sedangdirawat. Misalnya, tanaman yang baru tumbuh membutuhkan unsur nitrogen (N) yang lebih, sedangkan tanaman yang akan berbuah membutuhkan unsur kalium (K) yang lebih. Pengetahuan tersebut bertujuan untuk menentukan bahan-bahan yang digunakan untuk pembutan pupuk kompos. Penentuan bahan yang sesuai dengan kebutuhan tanaman bisa dilakukan dengan melakukan pendekatan bahan baku. Setiap material organik memiliki kekhasan kandungan unsur-unsur. Misalnya, jerami, hijauan dan kotoran ayam memiliki kandungan $\mathrm{N}$ yang besar. Sehingga bahanbahan tersebut bisa dijadikan kompos yang kaya akan unsur N(Yuniwati dkk , 2012).

Pupuk kompos yang dihasilkan dari program pengabdian kepada masyarakat ini memiliki sifat fisik yang baik yaitu berwarna hitam dan tidak berbau busuk, pupuk kompos yang dihasilkan dapat dimanfaatkan untuk tanaman yang membutuhkan unsur $\mathrm{N}$ seperti sawi, kangkung dan selada karena pupuk yang dibuat bersumberdari jerami padi, dedaunan dan kotoran hewan yang banyak mengandung unsur $\mathrm{N}$

\section{SIMPULAN}

Pelatihan pembuatan pupuk
kompos guna memanfaatkan limbah
pertanian dan peternakan, menjadi sarana
pembelajaran bagi masyarakat khususnya
kelompok ibu-ibu tani Gampong Keuneu
Eu, Kecamatan Peukan Bada, Kabupaten


Aceh Besar, Provinsi Aceh untuk memanfaatkan limbah hasil pertanian dan peternakan menjadi pupuk kompos yang dapat dimanfaatkan kembali untuk pertanian.

\section{DAFTAR PUSTAKA}

Firmansyah, M. A. (2010). Teknik Pembuatan Kompos, Artikel, dalam Pelatihan Petani Plasma Kelapa Sawit di Kabupaten Sukamara, Kalimantan Tengah, (5 Oktober 2010).

Nurhayati, Ali, J., \& Rizqi, S. . (2011). Potensi Limbah Pertanian Sebagai Pupuk Organik Lokal di Lahan Kering Dataran Rendah Iklim Basah. Iptek Tanaman Pangan, 6(2), 193202.

Rahmawanti, N., \& Dony, N. (2014). Pembuatan Pupuk Organik Berbahan Sampah Organik Rumah Tangga dengan Penambahan Aktivator EM4 di Daerah Kayu Tangi. ZIRAA'AH, 39(1), 1-7.

Yanqoritha, N. (2013). Optimasi Aktivator dalam Pembuatan Kompos Organik dari Limbah Kakao. Majalah Ilmiah MEKTEK, 15(2), 103-108.

Yuniwati, M., Frendy, I., \& Adinigsih, P. (2012). Optimasi Kondisi Proses Pembuatan Kompos dari Sampah Organik dengan Fermentasi Menggunakan EM4. Jurnal Teknologi, 5(2), 172-181. 